\title{
Potential of cowpea [Vigna unguiculata (L.) Walp.] and guar [Cyamopsis tetragonoloba (L.) Taub.] as alternative forage legumes for the United Arab Emirates
}

\author{
N. K. Rao* and Mohammed Shahid \\ International Center for Biosaline Agriculture (ICBA), P.O. Box 14660, \\ Dubai, United Arab Emirates
}

\begin{abstract}
Investigations were conducted with an objective to identify alternative crops, especially legumes with low water requirement to replace the water intensive conventional species in forage production systems in the United Arab Emirates (UAE). Thus, the performance of 23 accession of cowpea (Vigna unguiculata) and 10 accessions of guar (Cyamopsis tetragonoloba) was evaluated over a growing period of 120 days during summer in 2009. In cowpea, the dry matter yield, averaged over the accessions was $18.1 \mathrm{t}$ $\mathrm{ha}^{-1}$ with accession TVu 9480 producing the maximum yield of $24 \mathrm{t} \mathrm{ha}^{-1}$. Seed yield varied from $1.1 \mathrm{t} \mathrm{ha}^{-1}$ (accession TVu 9604) to $4.9 \mathrm{t} \mathrm{ha}^{-1}$ (accession TVu 9510) among accessions with an average of $2.4 \mathrm{tha}^{-1}$. In guar, while the average dry matter yield of the 10 accessions was $9.5 \mathrm{t} \mathrm{ha}^{-1}$, accession PI 323083 produced the highest yield (12.8 $\mathrm{t} \mathrm{ha}^{-1}$ ). Seed yield varied between $2.5 \mathrm{t} \mathrm{ha}^{-1}$ (accession PI 263891) and $1.4 \mathrm{t} \mathrm{ha}^{-1}$ (accession PI 263877) with a mean of $2.2 \mathrm{t} \mathrm{ha}^{-1}$ over accessions. The results show that both cowpea and guar have great potential and because of their low water requirements, they could be excellent alternatives for the water-thirsty forage species such as alfalfa in the UAE. Both these crops are salt-tolerant and in addition, they are fast-growing high quality forages and have other economic uses, especially as vegetables.
\end{abstract}

Keywords: Alternative crops, cowpea, forage legumes, guar, United Arab Emirates, water demand.

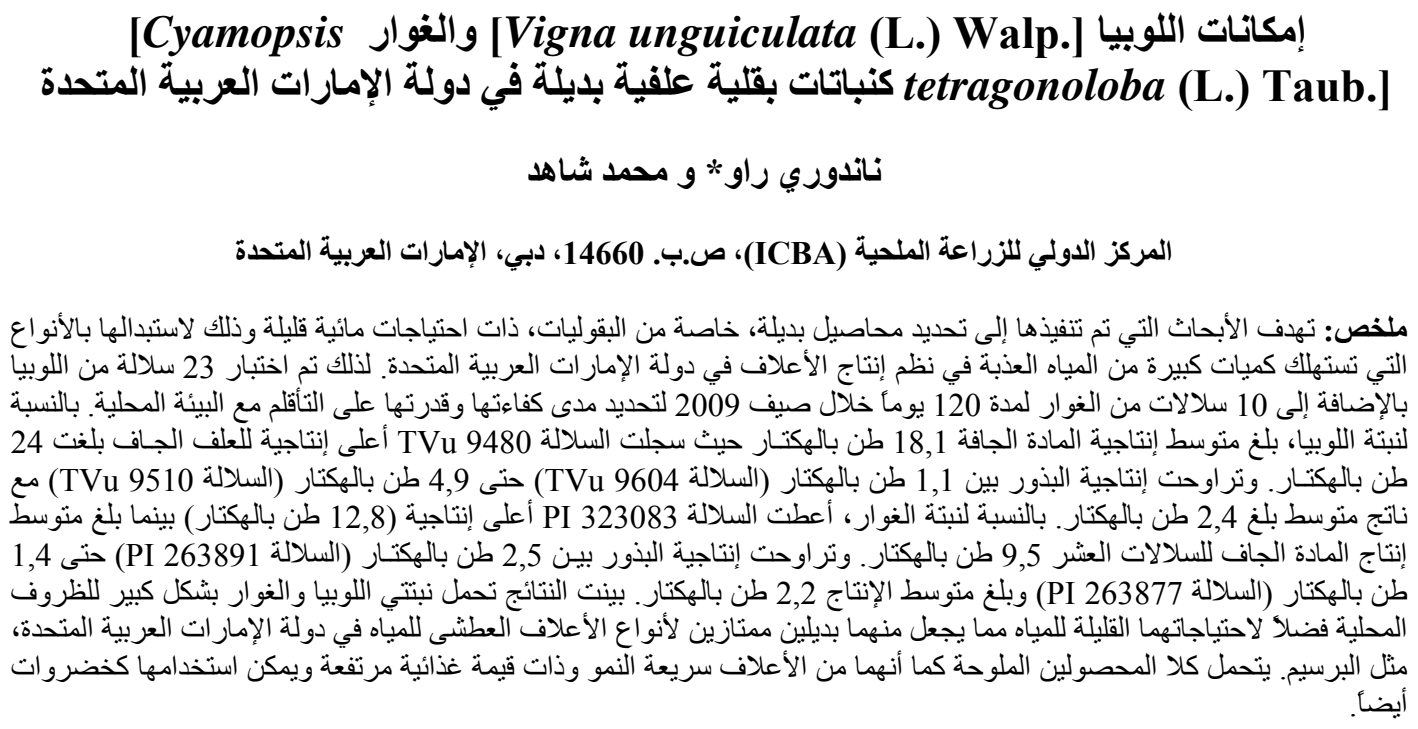

* Corresponding Author, Email: n.rao@biosaline.org.ae 


\section{Introduction}

In the United Arab Emirates (UAE), the livestock populations have grown substantially in recent years (EAD, 2009). Thus, the number of camel, sheep, goats and cows have increased by 15,13 and $23 \%$, respectively in 2006-07 compared to 2005-2006. Alfalfa (Medicago sativa L.) and Rhodes grass (Chloris gayana Kunth.) are the two main fodder crops grown in the UAE. Both these species require large quantities of water (up to $15,700 \mathrm{~m}^{3} \mathrm{ha}^{-1} \mathrm{yr}^{-1}$ ), often drawn from non-renewable groundwater sources. Large-scale cultivation of these species to meet the increased demand for forage has resulted in drastic reduction in groundwater levels and an increase in salinity due to intrusion of seawater, especially in the coastal areas. At the current rates of agricultural use, it is predicted that all of UAE's fresh and moderately brackish water resources will be exhausted in 20-40 years (EAD, 2009). Therefore, it is imperative that urgent measures should be taken to reduce water demand for the forage production and one way to achieve this is to look at other forage crops that need less water to grow. There are only limited systematic studies to date to evaluate the performance of alternative forage crops, especially legumes, under the UAE growing conditions, characterized by poor and erratic rainfall and high daytime summer temperatures, often exceeding $45^{\circ} \mathrm{C}$. The soils reflect the aridity of the climate as they are poorly developed, shallow and enriched with lime, gypsum, or salts. The harsh growing conditions, together with the shortage of fresh water resources and natural salinization of vast areas severely limit the number of crops that can be successfully grown in the UAE. In the present paper, we report the results of a study conducted at the International Center for Biosaline Agriculture (ICBA) research station, Dubai $\left(25^{\circ} 05^{\prime} 49^{\prime \prime} \mathrm{N}\right.$ and $\left.55^{\circ} 23^{\prime} 25^{\prime \prime} \mathrm{E}\right)$ to assess the performance of two multi-purpose drought-tolerant legumes, cowpea [Vigna unguiculata (L.) Walp.] and guar [Cyamopsis tetragonoloba (L.) Taub.] with the objective to identify alternative crops, to replace the water intensive conventional legume species in forage production systems.

Cowpea is an important food legume and a valuable component of the traditional cropping systems in semi-arid tropics covering Asia, Africa, Central and South America. Cowpea has many uses: the young leaves, green pods and green seeds are used as vegetables; and dry seeds are used in various food preparations (Singh et al., 2003) (Figure 1A-D). Cowpea is equally important as a nutritious fodder for livestock. The crude protein content in the grain and leaves ranges from 22 to $30 \%$ on a dry weight basis (in comparison, alfalfa has 18 to $20 \%$ protein) and from 13 to $17 \%$ in the haulms with a high digestibility and low fiber level (Tarawali et al., 1997). Controlled sheep feeding experiments have shown that feeding 200-400 g per day of haulms as a supplement to a basal diet of sorghum stover had $100 \%$ higher average live weight gain compared to animals fed with sorghum fodder alone (Singh et al., 2003).

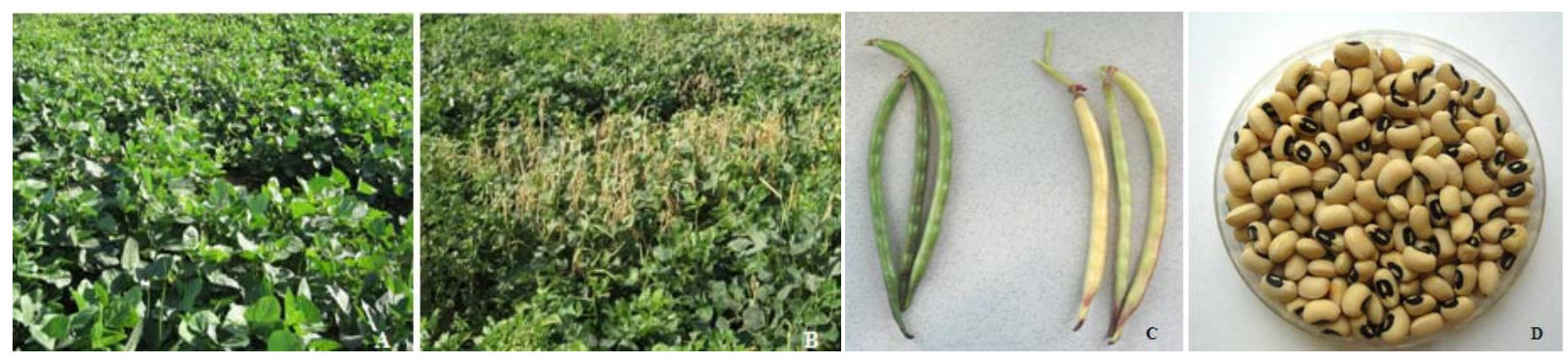

Figure 1. Cowpea at ICBA research station. (A) Vegetative growth stage; (B) Field trial; (C) Seed pods; and (D) Seeds. 
Guar is a summer annual legume crop grown in Asia as a vegetable for human consumption, forage for cattle, and as a green manure (Figure 2A-D). The endosperm of guar seed contains galactomannan gum which is gaining importance as a food and non-food item. Highly refined guar gum is used as a stiffener in soft ice cream, instant puddings and whipped cream substitutes, while lower grade guar gum is used in the textile, paper, petroleum, mining, pharmaceutical and cosmetic industries (Undersander et al., 1991).

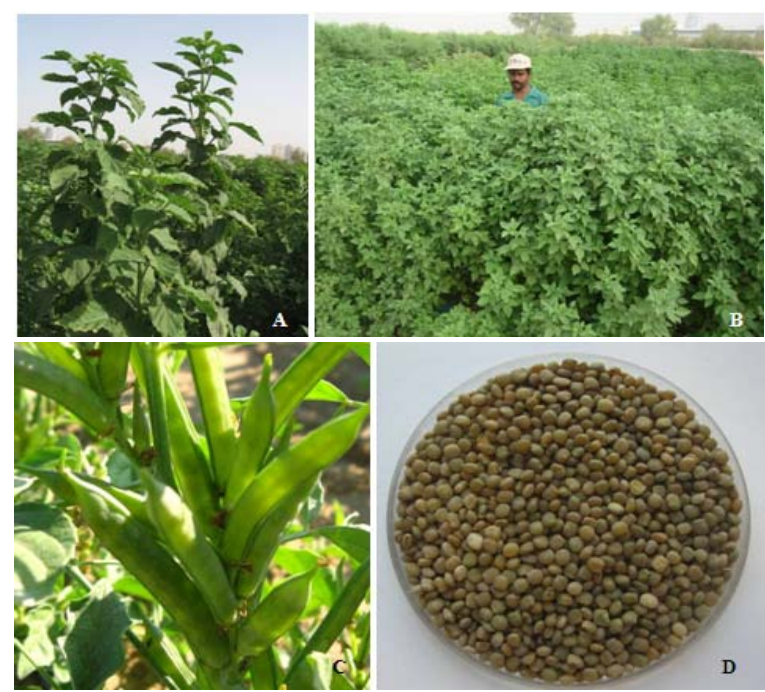

Figure 2. Guar at ICBA research station. (A) Vegetative growth stage; (B) Field trial; (C) Green pods; and (C) Seeds.

\section{Materials and methods}

Twenty three accessions of cowpea (Vigna unguiculata) obtained from the International Institute for Tropical Agriculture (IITA), Nigeria and 10 accessions of guar obtained from the Plant Genetic Resources Conservation Unit, Griffin, United States of America (USA) were used in this study (Table 1). The guar (Cyamopsis tetragonoloba) accessions were the ten top-performing accessions selected from an initial set of 100 accessions grown in 2007-08 at ICBA research station, Dubai. The soil at the experimental site was fine sand (ECe 1.2 $\mathrm{dS} \mathrm{^{-1 }}$ ) and moderately alkaline ( $\left.\mathrm{pH} 8.2\right)$ with very low organic matter $(<0.5 \%)$. The experiment was laid out in a randomized block design (RBD) with three replications. Sowings were done in late-February 2009. Each plot consisted of three rows each of $3 \mathrm{~m}$. The distance between rows within each plot was 50 $\mathrm{cm}$ and the distance between two adjacent plots was $1 \mathrm{~m}$. The distance between plants within each row was maintained at $25 \mathrm{~cm}$, corresponding with a population of 80,000 plants ha ${ }^{-1}$. The plants were irrigated with lowsalinity water of about $3 \mathrm{dS} \mathrm{m}^{-1}$ using the dripirrigation system. Water was applied once every day for $20 \mathrm{~min}$ at the rate of $41 \mathrm{~h}^{-1}$ plant $^{-1}$ until April and two times a day thereafter. The plots were not irrigated on rainy days. Before sowing, the fertility of the soil was improved by incorporating organic fertilizer at the rate of $40 \mathrm{t} \mathrm{ha}^{-1}$ and during crop growth two split doses of NPK (20:20:20) at the rate of $50 \mathrm{~kg}$ $\mathrm{ha}^{-1}$ were applied by banding alongside the rows. As a prophylactic treatment, micronutrients were applied (3-4 $\left.\mathrm{kg} \mathrm{ha}^{-1}\right)$ as foliar spray during vegetative growth. There were no major problems from diseases or insect pests, except Aphids when the plants were very young, which were controlled by insecticide spray (Dursban 4 EC).

Both the crops were harvested 118 to 120 days after sowing when $75 \%$ of the pods have 
turned brown. Standard agronomic data such as vine length, number of pods, seed weight and biomass (fresh and dry matter yields) were recorded from three plants, randomly selected from the middle row in each plot. The biomass and seed yield potential of individual accessions were estimated form the average single plant yields and expressed in $\mathrm{tha}^{-1}$. The data on pod and seed characteristics were based on 10 pods or seeds, randomly selected from the three plants used for agronomic observations. Dry mater yield was determined by drying the samples initially under the sun for two days and then in a forced-drought oven (Memmert, model ULP 800 ) at $80^{\circ} \mathrm{C}$ for 48 hrs. The data from each crop were subjected to analysis of variance (ANOVA) with the aid of the statistical software GenStat (Version 7.22 DE). The dry matter yields in alfalfa reported earlier from the UAE (Sattar et al., 2002) and other counties (FAO, 2009) were used to compare the productivity of cowpea and guar obtained in the present study.

Table 1. Passport information of cowpea and guar accessions.

\begin{tabular}{|c|c|c|c|}
\hline Crop & Accession number & Alternate Identity & Origin \\
\hline Cowpea & $\begin{array}{l}\text { TVu } 9443 \\
\text { TVu } 9446 \\
\text { TVu } 9461 \\
\text { TVu } 9468 \\
\text { TVu } 9480 \\
\text { TVu } 9498 \\
\text { TVu } 9499 \\
\text { TVu } 9510 \\
\text { TVu } 9514 \\
\text { TVu } 9557 \\
\text { TVu } 9596 \\
\text { TVu } 9604 \\
\text { TVu } 9615 \\
\text { TVu } 9620 \\
\text { TVu } 9621 \\
\text { TVu } 9651 \\
\text { TVu } 9663 \\
\text { TVu } 9666 \\
\text { TVu } 9671 \\
\text { TVu } 9701 \\
\text { TVu } 9716 \\
\text { TVu } 9725 \\
\text { TVu } 9751\end{array}$ & $\begin{array}{l}\text { Sahragt El-Kubra Balack Eye } 1 \\
\text { Sahragt El-Kubra Red Eye } 6 \\
\text { Mansura No Eye } 2 \\
\text { Mansura No Eye } 6 \\
\text { Mansura Red Eye } 14 \\
\text { Kafr Westany No Eye } 3 \\
\text { Ex Kafr Westany } \\
\text { El Hawashm Black Eye } 1 \\
\text { El Hawashm No Eye } 1 \\
\text { Zagazig No. } 6 \\
\text { Tanta Black Eye } 4 \\
\text { Kharsit Brown Eye } \\
\text { Ibyar Black Eye } 2 \\
\text { Ibyar Red Eye } 6 \\
\text { Ibayar No Eye } 7 \\
\text { Kafr El-Sheik No. } 4 \\
\text { Kafr El-Sheik No Eye } 3 \\
\text { Kafr El-Sheik No Eye } 4 \\
\text { Kafr El-Sheik No. } 10 \\
\text { Fuwa Black Eye } \\
\text { Damanhur No Eye } 1 \\
\text { Abu Hummus No Eye } 1 \\
\text { El-Faiyum No. } 4\end{array}$ & $\begin{array}{l}\text { Egypt } \\
\text { Egypt } \\
\text { Egypt } \\
\text { Egypt } \\
\text { Egypt } \\
\text { Egypt } \\
\text { Egypt } \\
\text { Egypt } \\
\text { Egypt } \\
\text { Egypt } \\
\text { Egypt } \\
\text { Egypt } \\
\text { Egypt } \\
\text { Egypt } \\
\text { Egypt } \\
\text { Egypt } \\
\text { Egypt } \\
\text { Egypt } \\
\text { Egypt } \\
\text { Egypt } \\
\text { Egypt } \\
\text { Egypt } \\
\text { Egypt }\end{array}$ \\
\hline Guar & $\begin{array}{l}\text { PI } 158129 \\
\text { PI } 262152 \\
\text { PI } 263877 \\
\text { PI } 263882 \\
\text { PI } 263891 \\
\text { PI } 263896 \\
\text { PI } 323083 \\
\text { PI } 426631 \\
\text { PI } 426643\end{array}$ & $\begin{array}{l}\text { Pardeshi } \\
\text { IC-83 NO } 3 \\
\text { IC } 547 \\
\text { IC } 2488 \\
\text { IC } 5493 \\
\text { IC } 5498 \\
- \\
\text { K-14 } \\
\text { K-827 }\end{array}$ & $\begin{array}{l}\text { India } \\
\text { Pakistan } \\
\text { India } \\
\text { India } \\
\text { India } \\
\text { India } \\
\text { India } \\
\text { Pakistan } \\
\text { Pakistan }\end{array}$ \\
\hline
\end{tabular}




\section{Results and Discussion}

The average minimum and maximum temperatures during the cropping period were 24.1 and $34.7^{\circ} \mathrm{C}$, respectively. The total rainfall during crop duration was $47 \mathrm{~mm}$, which was received during March and April.

\section{Cowpea}

Significant differences were observed among the accessions in vine length, days to flowering, pods per plant, pod length, 100 seed weight and seed yield, indicating considerable genetic variability for these traits $(p<0.05)$ (Table 2). Vine length ranged between 86.5 and $251.1 \mathrm{~cm}$ among accessions with an average of $170.7 \mathrm{~cm}$. While the majority of accessions are semi-spreading and had longer vines, semi-erect accessions such as TVu 9484,
9621 and 9666 had shorter vines. The number of pods per plant varied from 15 to 74 among accessions with a mean of 34.9. Seed yield varied between 1.1 and $4.9 \mathrm{t} \mathrm{ha}^{-1}$ with a mean of $2.3 \mathrm{t} \mathrm{ha}^{-1}$ over accessions. Both the number of pods and seed yield were maximum in accession $\mathrm{TVu} 9510$ (74 and $4.9 \mathrm{t} \mathrm{ha}^{-1}$, respectively), followed by TVu 9498 (53.3 and $3.1 \mathrm{t} \mathrm{ha}^{-1}$, respectively) (Table 2). Seed yields in accessions $\mathrm{TVu} 9651, \mathrm{TVu} 9663, \mathrm{TVu} 9671$ and $\mathrm{TVu} 9725$ also were high $\left(\approx 3.0 \mathrm{t} \mathrm{ha}^{-1}\right)$ and very similar to those reported from preliminary evaluation at ICBA research station in 2007-08 (Rao et al., 2009), indicating that cowpea has good adaptation to the local growing conditions.

Table 2. Growth and yield parameters of 23 cowpea accessions.

\begin{tabular}{llllllll}
\hline $\begin{array}{l}\text { Accession } \\
\text { number }\end{array}$ & $\begin{array}{l}\text { Vine } \\
\text { length } \\
\text { (cm) }\end{array}$ & $\begin{array}{l}\text { Days } \\
\text { flowering }\end{array}$ & $\begin{array}{l}\text { Pods per } \\
\text { plant }\end{array}$ & $\begin{array}{l}\text { Pod } \\
\text { length } \\
\text { (cm) }\end{array}$ & $\begin{array}{l}\text { Seed per } \\
\text { pod }\end{array}$ & $\begin{array}{l}100 \text { seed } \\
\text { weight } \\
\text { (g) }\end{array}$ & $\begin{array}{l}\text { Seed } \\
\text { yield } \\
\text { (t ha-1) }\end{array}$ \\
\hline TVu 9443 & 231.9 & 67 & 40.6 & 13.1 & 8.9 & 16.47 & 2.69 \\
TVu 9446 & 245.4 & 65 & 20.0 & 13.8 & 9.8 & 12.63 & 1.35 \\
TVu 9461 & 243.7 & 66 & 17.7 & 12.7 & 9.1 & 13.00 & 1.11 \\
TVu 9468 & 133.8 & 65 & 37.1 & 13.3 & 10.9 & 10.99 & 2.01 \\
TVu 9480 & 206.2 & 61 & 37.4 & 14.7 & 9.9 & 12.75 & 2.31 \\
TVu 9498 & 86.7 & 63 & 53.5 & 12.8 & 10.5 & 12.49 & 3.13 \\
TVu 9499 & 175.1 & 68 & 20.1 & 12.3 & 9.4 & 11.61 & 1.14 \\
TVu 9510 & 102.4 & 56 & 74.0 & 13.8 & 10.4 & 14.63 & 4.88 \\
TVu 9514 & 161.0 & 67 & 32.7 & 14.8 & 10.4 & 11.22 & 2.28 \\
TVu 9557 & 179.9 & 64 & 36.4 & 11.2 & 8.5 & 14.14 & 2.35 \\
TVu 9596 & 193.8 & 64 & 31.5 & 13.6 & 9.9 & 12.37 & 2.49 \\
TVu 9604 & 251.1 & 67 & 15.3 & 13.7 & 9.6 & 12.34 & 1.05 \\
TVu 9615 & 182.1 & 63 & 28.2 & 12.7 & 10.0 & 13.76 & 2.39 \\
TVu 9620 & 237.0 & 62 & 20.0 & 13.4 & 8.8 & 14.98 & 1.57 \\
TVu 9621 & 86.5 & 65 & 33.4 & 14.2 & 9.4 & 15.01 & 2.40 \\
TVu 9651 & 185.2 & 54 & 33.2 & 13.3 & 8.5 & 20.07 & 3.01 \\
TVu 9663 & 101.3 & 56 & 42.8 & 15.5 & 11.9 & 13.19 & 2.95 \\
TVu 9666 & 89.7 & 61 & 36.5 & 13.0 & 9.1 & 12.81 & 2.15 \\
TVu 9671 & 194.0 & 62 & 37.2 & 13.5 & 8.7 & 19.08 & 2.86 \\
TVu 9701 & 174.4 & 56 & 31.2 & 14.0 & 10.1 & 16.35 & 2.76 \\
TVu 9716 & 157.4 & 60 & 38.0 & 13.5 & 9.9 & 13.25 & 2.44 \\
TVu 9725 & 119.8 & 63 & 43.4 & 13.5 & 10.4 & 12.91 & 2.92 \\
TVu 9751 & 186.7 & 60 & 42.1 & 10.3 & 8.9 & 9.87 & 2.22 \\
Mean & 170.7 & 63.7 & 34.9 & 13.3 & 9.7 & 13.74 & 2.34 \\
LSD 9.05$)$ & 54.8 & 6.1 & 21.9 & 1.1 & $2.5(\mathrm{~ns})$ & 2.32 & 1.7 \\
\hline
\end{tabular}


In contrast to the pod number and seed yield, differences in fresh and dry matter yield between accessions were not statistically significant $(P>0.05)$ (Figure 3). Averaged over accessions, the green forage (fresh) and dry matter yields were 77.8 and $18.1 \mathrm{t} \mathrm{ha}^{-1}$, respectively. While the fresh matter yield was maximum in accession TVu $9499\left(104.8 \mathrm{t} \mathrm{ha}^{-1}\right)$, several accessions produced green forage yields in excess of $85 \mathrm{t} \mathrm{ha}^{-1}$. The dry matter yield was highest in accession TVu 9480 (24 $\left.\mathrm{t} \mathrm{ha}^{-1}\right)$, followed by TVu 9499 and TVu 9515 (21.6 $\mathrm{t} \mathrm{ha}^{-1}$ in both). Furthermore, yields in several other accessions were close to or above $20 \mathrm{t} \mathrm{ha}^{-1}$, indicating their high forage potential (Figure 3).

\section{․ Fresh matter Dry matter}

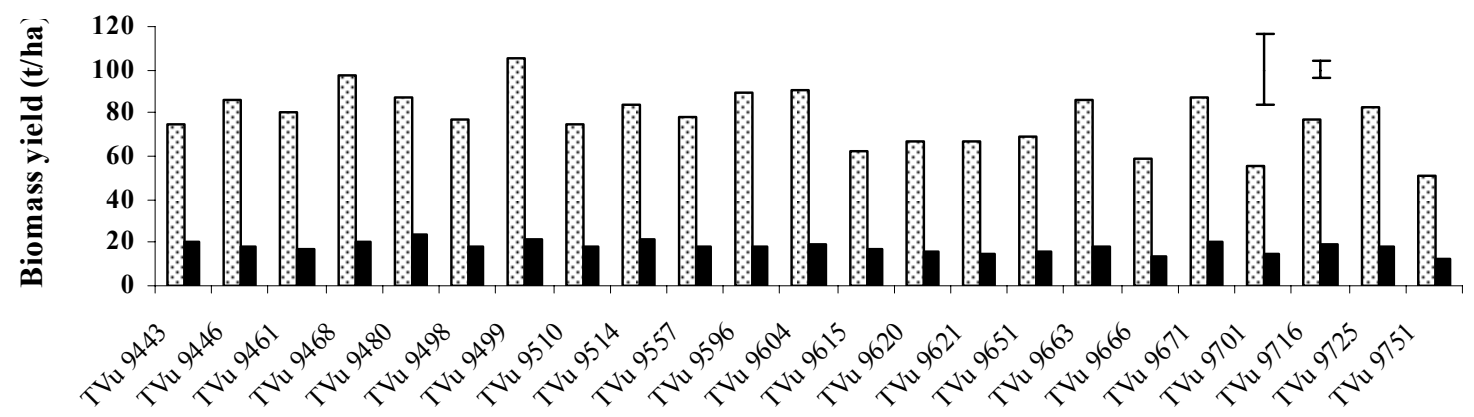

Accession number

Figure 3. Fresh and dry matter yields of 23 cowpea accessions. Vertical bars represent LSD values at $P$ $\leq \mathbf{0 . 0 5}$ for fresh (left bar) and dry (right bar) matter yields, respectively.

In previous studies on cowpea, Ibrahim et al. (2006) obtained green forage yields of 22.6 $\mathrm{t} \mathrm{ha} \mathrm{a}^{-1}$ and dry matter yields of over $4 \mathrm{t} \mathrm{ha}^{-1}$. Mullen (1999) reported cowpea dry matter yields ranging from $500 \mathrm{~kg} \mathrm{ha}^{-1}$ under dryland conditions to over $4000 \mathrm{~kg} \mathrm{ha}^{-1}$ under favorable conditions in New South Wales, Australia. The average fresh and dry matter yields (77.8 and $18.1 \mathrm{t} \mathrm{ha}^{-1}$, respectively) obtained in our study were considerably higher than those reported from other regions. However, in the absence of sufficient information on the cultivar and stage of plant development at harvest in the previous reports, it is imprudent to make a direct comparison of the yields obtained in the present study.

In cowpea, there are many studies on crop water requirement and crop water use mainly in relation to seed yield. For instance, in Nigeria, Fapohunda et al. (1984) obtained yields up to $1.9 \mathrm{t} \mathrm{ha}^{-1}$ using $464 \mathrm{~mm}$ of water. In northeastern Brazil, Andrade et al. (2002) obtained yields of $2.9 \mathrm{t} \mathrm{ha}^{-1}$ with $449 \mathrm{~mm}$. The normal seasonal water use for cowpea in the San Joaquin Valley of California was reported to be $669 \mathrm{~mm}$ and grain yields ranging from about 4.7 to $5.9 \mathrm{t} \mathrm{ha}^{-1}$ were obtained, depending on the variety and season. Although information on water use was not presented, Mullen et al. (2003) reported average seed yields varying between 1.5 and $2 \mathrm{t} \mathrm{ha}^{-1}$ from Australia. In our study, while the seed yield in accession TVu 9510 (4.9 $\mathrm{t} \mathrm{ha}^{-1}$ ) was similar to the yields obtained in San Joaquin Valley (DeTar, 2009), several other accessions produced yields close to $3 \mathrm{tha}^{-1}$, comparable to that reported by Andrade et al. (2002). Thus, cowpea appears to have excellent potential for cultivation, both as forage and a grain legume in the UAE.

\section{Guar}

In guar, growth was slow during the first two months but became profuse after flowering and pod formation. Except for plant height, no significant differences were found among accessions for other agronomic traits, including 
seed and forage yield $(P>0.05)$ (Table $3 \&$ Figure 4$)$. The similarity in seed and forage yields of the ten accessions was probably because they were selected beforehand for their superior performance after preliminary evaluation of a set of 100 accessions (see material and methods). The mean number of pods per plant varied from 164.4 (accession IP 263891) to 113.4 (accession PI 263877) among accessions with a mean of 149.4. Seed yield varied between $2.5 \mathrm{t} \mathrm{ha}^{-1}$ (accession PI 263891) and $1.4 \mathrm{t} \mathrm{ha}^{-1}$ (accession PI 263877) with a mean of $2.2 \mathrm{t} \mathrm{ha}^{-1}$ over accessions (Table 3 ). Averaged over accessions, fresh matter yield was $27.6 \mathrm{t} \mathrm{ha}^{-1}$. It was highest in accession PI $323083\left(39.2 \mathrm{t} \mathrm{ha}^{-1}\right)$, followed by PI 263877 (33.6 $\mathrm{t} \mathrm{ha}^{-1}$ ) (Figure 4). The dry matter yield, averaged over accessions was found to be $9.5 \mathrm{t}$ $\mathrm{ha}^{-1}$ with accession PI 323083 producing the highest yield (12.8 $\left.\mathrm{t} \mathrm{ha}^{-1}\right)$, followed by PI 263877 and PI 158123 (11.2 $\mathrm{t} \mathrm{ha}^{-1}$ in both).

Table 3. Growth and yield parameters of 10 guar accessions.

\begin{tabular}{clllllll}
\hline $\begin{array}{c}\text { Accession } \\
\text { number }\end{array}$ & $\begin{array}{l}\text { Plant } \\
\text { height } \\
\text { (cm) }\end{array}$ & $\begin{array}{llll}\text { Pods per } \\
\text { plant }\end{array}$ & $\begin{array}{l}\text { Pod } \\
\text { length } \\
\text { (cm) }\end{array}$ & $\begin{array}{l}\text { Pod } \\
\text { width } \\
\text { (mm) }\end{array}$ & $\begin{array}{l}\text { Seeds } \\
\text { per pod }\end{array}$ & $\begin{array}{l}\text { 100 seed } \\
\text { weight } \\
\text { (g) }\end{array}$ & $\begin{array}{l}\text { Seed } \\
\text { yield } \\
\left.\text { (t ha }{ }^{-1}\right)\end{array}$ \\
\hline PI 158123 & 108.7 & 144.7 & 7.0 & 7.3 & 8.0 & 3.6 & 2.42 \\
PI 158129 & 79.3 & 158.4 & 5.8 & 6.4 & 7.7 & 3.1 & 2.39 \\
PI 262152 & 89.8 & 142.0 & 5.6 & 6.4 & 7.7 & 3.1 & 1.84 \\
PI 263877 & 87.3 & 113.4 & 5.6 & 6.7 & 7.1 & 3.4 & 1.38 \\
PI 263882 & 91.3 & 163.8 & 5.4 & 6.3 & 6.9 & 3.1 & 2.31 \\
PI 263891 & 98.8 & 164.4 & 5.5 & 6.6 & 7.7 & 3.3 & 2.50 \\
PI 263896 & 86.0 & 161.6 & 5.6 & 6.5 & 7.3 & 3.2 & 2.46 \\
PI 323083 & 112.9 & 157.0 & 5.9 & 6.8 & 7.8 & 3.1 & 2.44 \\
PI 426631 & 83.5 & 161.9 & 5.7 & 6.5 & 7.1 & 3.2 & 2.01 \\
PI 426643 & 87.6 & 126.8 & 5.5 & 6.7 & 7.5 & 3.4 & 1.91 \\
Mean & 92.5 & 149.4 & 5.8 & 6.6 & 7.5 & 3.2 & 2.17 \\
LSD (0.05) & 22.1 & $85.0(n s)$ & $1.3(n s)$ & $0.6(n s)$ & $1.1(n s)$ & $0.5(n s)$ & $1.2(n s)$ \\
\hline ns: not significant & & & & & & &
\end{tabular}

Fresh matter Dry matter

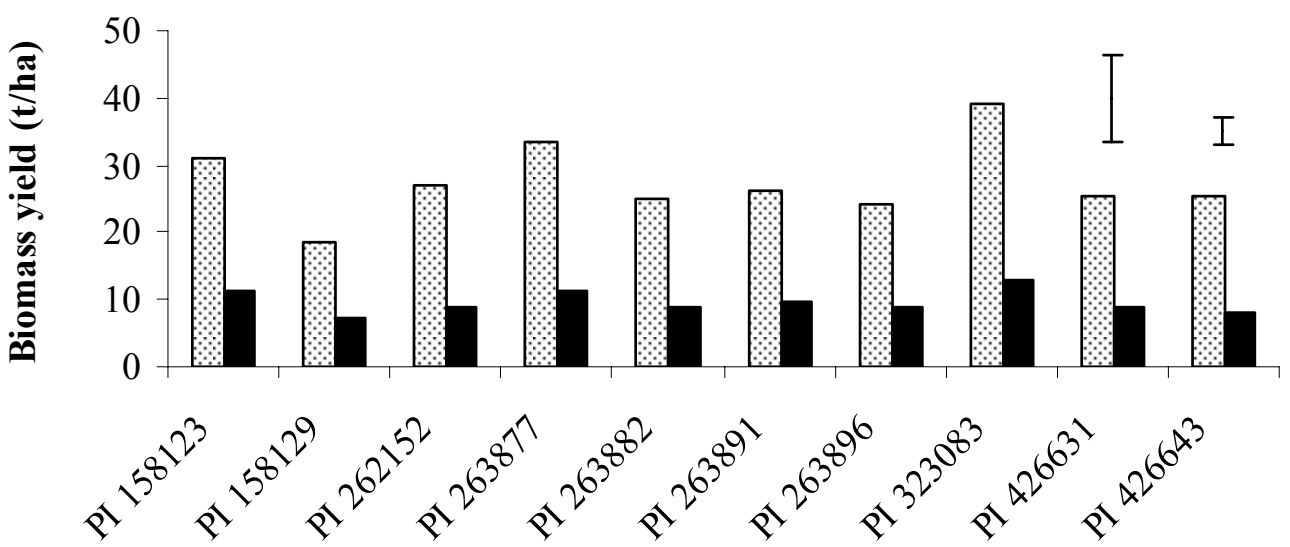

Accession number

Figure 4. Fresh and dry matter yields of 10 guar accessions. The vertical bars represent LSD values at $P \leq \mathbf{0 . 0 5}$ for the fresh (left bar) and dry (right bar) matter yields, respectively. 
In guar, production practices and rainfall during growing season cause seed yields to vary from $340-2250 \mathrm{~kg} \mathrm{ha}^{-1}$ (Undersander et al., 1991). More recently, Rao and Northup (2009a) evaluated the forage yield and nutritive value of four tropical annual legumes, including guar in the southern Great Plains of USA. Biomass production (dry weight) over four years averaged at $3321 \mathrm{~kg} \mathrm{ha}^{-1}$ showing high potential as a summer forage legume other than soybean. In guar, green forage yields of over $30 \mathrm{tha}^{-1}$ and dry forage yields between 11 and $14 \mathrm{t} \mathrm{ha}^{-1}$ were obtained in field trials conducted in the Central region of Saudi Arabia, (Al-Shaikh, 2004), parallel to the mean yields reported in this paper.

Guar is known for its drought tolerance and grows without irrigation even in areas with as little as $250 \mathrm{~mm}$ of annual rainfall (Undersander et al., 1991). However, there are only limited studies on the water requirements and water-use of guar in relation to forage and seed yields. Studies conducted at Wad Medani, Sudan showed that the crop water requirement was about $682 \mathrm{~mm}$ with mean seed yield of about $1000 \mathrm{~kg} \mathrm{ha}^{-1}$ (Abbas et al., 2008). In trials carried over four years in southern Great Plains of USA, with precipitation between 184 and $485 \mathrm{~mm}$ during the growing seasons, seed yields ranging from 897 to $2730 \mathrm{~kg} \mathrm{ha}^{-1}$ were obtained (Rao and Northup, 2009b). Seed yields obtained in our study are close to the highest reported yields from the USA, indicating that guar has excellent promise also as a grain legume for the UAE.

In general, the forage yield of crops varies with climate and length of total growing period and the genotype. In alfalfa, hay yields after the first year range from 2 to $2.5 \mathrm{t} \mathrm{ha}^{-1}$ per cut of about 25 to 30 day cutting interval (FAO, 2009). For instance, in Hofuf, Saudi Arabia, 28 $\mathrm{t} \mathrm{ha}^{-1}$ of hay over 310 days involving 12 cuts and in Davis, California, $22 \mathrm{t} \mathrm{ha}^{-1}$ of hay over 200 day growing period involving 7 cuts were reported (FAO, 2009). The crop water requirements for alfalfa vary between 800 and $1600 \mathrm{~mm} /$ growing period depending on climate and length of growing period. In a field trial conducted in the northern agricultural region of the UAE, forage yields ( $15 \%$ moisture content) ranging between 30.3 and $24.3 \mathrm{t} \mathrm{ha}^{-1}$ were obtained with three levels of irrigation (2000, 1800 and $1600 \mathrm{~mm}$ per growing season) (Sattar et al., 2002).

The results reported in this paper show that both guar and cowpea are fast growing legumes compared to alfalfa. For instance, the dry matter yield of up to $24 \mathrm{t} \mathrm{ha}^{-1}$ achieved in cowpea was over a relatively short growing period of 120 days, compared to the 24-30 t ha ${ }^{-1}$ yield of alfalfa obtained over 336 days in the UAE by Sattar et al. (2002). Especially, cowpea being day neutral, it should be possible to grow the crop throughout the year. In fact, studies conducted at ICBA demonstrated the excellent potential of cowpea even as a winter forage (ICBA, 2009).

In our study, although water requirements of cowpea and guar have not been studied, based on literature, water requirements in relation to production are expected to be low compared to Alfalfa. The additional advantage with cowpea and guar is that these are multipurpose crops. In addition to being highly nutritive forages, the green pods can be used as vegetable and dry pods harvested for grain with various uses including industrial as in case of guar. In terms of salinity tolerance, both cowpea and guar also appear to be more tolerant than alfalfa. In alfalfa, while the salinity threshold (ECe) was reported to be 2.0 $\mathrm{dS} \mathrm{m} \mathrm{m}^{-1}$ (FAO, 2009), cowpea and guar have thresholds of 4.9 and $8.1 \mathrm{dS} \mathrm{m}^{-1}$, respectively (West and Francois, 1982; Francois et al., 1990). In effect, guar has been found to be more salt-tolerant than many other grain legumes, including soybean (Keating and Fisher, 1985).

\section{Conclusions}

The identification and introduction of new drought-tolerant crops are important means to sustain forage production systems stressed with diminishing quality and quantity of irrigation water. New crops also serve the strategic interests of the nation by providing domestic sources of materials to reduce imports and contribute to increased farm income by diversifying products. The results from the field trial presented here show that cowpea and guar have good adaptation and high forage 
potential and because of their low water requirements, they could be excellent alternatives to replace the widely cultivated but water-thirsty alfalfa in the forage production systems. Both these crops are also multipurpose with several other economic uses, especially as vegetables. The forage and seed yields reported in this paper have been obtained under minimal management and higher yields could be expected through screening a wider range of germplasm and development of improved agronomic practices. Successful development of these alternative crops and transfer of technology to the farmers nevertheless requires further agronomic research. At the same time, comparative studies with alfalfa on water requirements, water-use efficiency, salinity tolerance, in addition to a cost-benefit analyses of production (taking into consideration the multiple uses of the crops) are suggested to further evaluate the potential of these crops for production systems in the UAE.

\section{Acknowledgements}

We are thankful to the International Institute of Tropical Agriculture (IITA), Ibadan, Nigeria, and the Plant Genetic Resources Conservation Unit, Griffin, Georgia, USA for providing the seeds of cowpea and guar, respectively.

\section{References}

Abbas, I. M. I., H. Adam and A. M. Adeeb. 2008. Measuring crop coefficient of guar (Cyamopsis tetragonoloba (L.) Taub) under Gezira, Sudan conditions. (Abstr.). http://www.tropentag.de/2008/proceedings/ node398.html

Al-Shaikh, A. A. 2004. Effect of irrigation interval, nitrogen and phosphorus applications on forage yield, carbohydrate and protein content of guar (Cyamopsis tetragonoloba) in the central region of Saudi Arabia. Saudi J. Biol. Sci. 11:3-8.

Andrade, Jr., A. S., B. H. N. Rodrigues, J. A. Frizzone, M. J. Cardoso, E. A. Bastos and F. B. Melo. 2002. Irrigation levels in the cultivation of cowpea. Rev. Bras. Eng. Agrí. Amb. 6:17-20.

DeTar, W. R. 2009. Crop coefficients and water use of cowpea in San Joaquin Valley of California. Agric. Water Manage. 96:5366.

EAD (Environment Agency-Abu Dhabi). 2009. Abu Dhabi Water Resources Master Plan. Environment Agency-Abu Dhabi, UAE.

FAO (Food and Agriculture Organization of the United Nations). 2009. Crop Water Information: Alfalfa. http://www.fao.org /nr/water/cropinfo_alfalfa.html

Fapohunda, H. O., P. O. Aina and M. M. Hossain. 1984. Water use-yield relations for cowpea and maize, Agric. Water Manage. 9:219-224.

Francois, L. E., T. J. Donovon and E. V. Maas. 1990. Salinity effects on emergence, vegetative growth and seed yield of guar. Agron. J. 82:587-592.

Ibrahim, M., M. Rafiq, A. Sultan, M. Akram and M. A. Goheer. 2006. Green fodder yield and quality evaluation of maize and cowpea sown alone and in combination. J. Agric. Res. 44:15-21.

ICBA (International Center for Biosaline Agriculture). 2009. Annual Report Highlights $2008 \quad$ (1428-29H). http://www.biosaline.org/admin/pressreleas es/ICBA\%20English\%20Annual\%20Repor $\mathrm{t} \% 20$ Highlight $\% 202008$.pdf

Keating, B. A. and M. J. Fisher. 1985. Comparative tolerance of tropical grain legumes to salinity. Aust. J. Agric. Res. 36:373-383.

Mullen, C. 1999. Summer legume forage crops: cowpeas, lablab and soybeans. http://www.dpi.nsw.gov.au/agriculture/field /field-crops/forage-fodder/crops/summerlegume-forage

Mullen, C. L., J. F. Holland and L. Heuke. 2003. AGFACTS: Cowpea, lablab and pigeon pea. http://www.dpi.nsw.gov.au 
/ data/assets/pdf_file/0006/157488/cowpea -lablab-pigeon-pea.pdf

Rao, N. K., M. Shahid and S. A. Shahid. 2009. Alternative crops for diversifying production systems in the Arabian Peninsula. Arab Gulf J. Sci. Res. 27:195203.

Rao, S. C. and B. K. Northup. 2009a. Capabilities of four novel warm-season legumes in the southern Great Plains: biomass and forage quality. Crop Sci. 49:1096-1102.

Rao, S. C. and B. K. Northup. 2009b. Capabilities of four novel warm-season legumes in the southern Great Plains: grain production and quality. Crop Sci. 49:11031108.

Sattar, H., M. Mehrazi, M. Awartani and A. R. Awad. 2002. Alfalfa crop water requirement study in the United Arab Emirates. Emir. J. Agri. Res. 4:12-24.

Singh, B. B., H. A. Ajeigbe, S. A. Tarawali, S. Fernandez-Rivera, M. Abubakar. 2003. Improving the production and utilization of cowpea as food and fodder. Field crops Res. 84:169-177.
Tarawali, S. A., B. B. Singh, M. Peters and S. F. Blade. 1997. Cowpea haulms as fodder. In: B. B. Singh, D. R. Mohan Raj, K. Dashiell and L. E. N. Jackai (Eds.). pp. 313-325. Advances in Cowpea Research. Co-publication of International Institute of Tropical Agriculture (IITA) and Japan International Centre for Agricultural Sciences (JIRCAS), IITA, Ibadan, Nigeria.

Undersander, D. J., D. H. Putnam, A. R. Kaminski, K. A. Kelling, J. D. Doll, E. S. Oplinger and J. L. Gunsolus.' 1991. Guar. In: Alternative Field Crop Manual. University of Wisconsin Cooperative Extension Service, University of Minnesota Extension Service, Center for Alternative Plant and Animal Products. http://www.hort.purdue.edu/newcrop/afcm/ cowpea.html

West, D. W. and L. E. Francois. 1982. Effects of salinity on germination, growth and yield of cowpea, Irrig. Sci. 3:169-175. 